\title{
Targeting of cell death and neuroinflammation with peptide-linked iron oxide nanoparticles and Gd-DTPA in a mouse model of Parkinson's disease
}

\author{
Coralie Sclavons $^{1}$, Sébastien Boutry ${ }^{2}$, Sophie Laurent ${ }^{1,2}$, Luce Vander Elst ${ }^{1,2}$, Robert N. Muller ${ }^{1,2}$ \\ 1. Department of General, Organic and Biomedical Chemistry, NMR and Molecular Imaging Laboratory, University of Mons, \\ Mons, Belgium. 2. Center for Microscopy and Molecular Imaging (CMMI), Charleroi, Belgium. \\ Correspondence: Sophie Laurent. Address: Department of General, Organic and Biomedical Chemistry, NMR and \\ Molecular Imaging Laboratory, University of Mons, 19, Avenue Maistriau B-7000 Mons, Belgium. \\ Email: sophie.laurent@umons.ac.be.
}

Received: June 17, 2015

DOI: $10.5430 /$ jbei.v2n1p13
Accepted: September 7, 2015

URL: http://dx.doi.org/10.5430/jbei.v2n1p13

\begin{abstract}
Parkinson's disease (PD) is one of the most common neurodegenerative disease and remains difficult to diagnose by conventional methods of early detection. It is characterized by the apoptotic loss of dopaminergic neurons (DN) and a neuroinflammation mainly located in the ventral midbrain (VM).
\end{abstract}

The aim of this work is to study new vectorized contrast agents for magnetic resonance imaging (MRI) detection of PD injured areas by targeting apoptosis and inflammation. Two peptides selected by phage display were used for the experiments: R826 peptide, selected for its affinity for the phosphatidylserine (PS) exposed at the external surface of apoptotic cells, and $2 \mathrm{C}$ peptide, selected for its affinity for TNF- $\alpha$ (tumor necrosis factor alpha), one of the most abundant cytokines secreted during inflammation. These peptides were grafted to pegylated iron oxide nanoparticles (PEG-USPIO) and gadolinium-diethylenetriamine pentaacetic acid (Gd-DTPA) for in vitro and in vivo studies, respectively. PD was simulated on mice with the MPTP (1-methyl-4-phenyl-1, 2, 3, 6-tetrahydropyridine) neurotoxin and its active metabolite $\mathrm{MPP}^{+}$(1-methyl-4-phenylpyridinium) for in vitro studies.

The results showed that PEG-USPIO-R826 and PEG-USPIO-2C enabled the detection of apoptosis and inflammation, respectively, on $\mathrm{MPP}^{+}$-treated culture cells. PEG-USPIO-2C also allowed detection of inflammation on histological brain sections of MPTP-treated mice. The $2 \mathrm{C}$ peptide grafted to Gd-DTPA showed encouraging results in MRI detection of injured brain areas in MPTP-treated mice. These observations suggest that a targeting of damaged cells and injured areas by these new specific contrast agents occurs, offering a new tool for early diagnosis of neurodegenerative disorders like PD by MRI.

\section{Keywords}

MRI, Apoptosis, Inflammation, Parkinson's disease, TNF- $\alpha$ 


\section{Introduction}

Parkinson's disease (PD) is one of the most common neurodegenerative diseases, after Alzheimer disease (AD) ${ }^{[1]}$. The main features of PD are slowness of movements, compromise of balance, muscle rigidity, and tremor ${ }^{[2]}$. The disease is caused by a massive loss of dopaminergic neurons (DN), and the resulting decrease of dopamine levels in the midbrain, associated with a massive astrogliosis and the presence of activated microglial cells ${ }^{[3]}$. Even though the cause of neuronal death is unclear, there is some evidence that loss of DN is due to an apoptotic pathway ${ }^{[4]}$. In the early stage of apoptosis, changes occur at the cell surface like the translocation of phosphatidylserine (PS) from the inner side of the plasma membrane to the outer layer ${ }^{[5]}$. These morphological changes lead to PS exposure at the external surface of the cell and this allows it to serve as a biomarker for targeting apoptosis.

On the other hand, neuroinflammation promotes the expression of a large amount of pro-inflammatory cytokines, like interleukines (IL) and tumor necrosis factor alpha (TNF- $\alpha$ ), which can be present in two distinct active forms. TNF- $\alpha$, like many other cytokines, is first synthesized as a transmembrane precursor that can stay on the cell surface or is processed to release the soluble form via proteolytic cleavage ${ }^{[6]}$. Several cells express TNF- $\alpha$, including neuronal cells (glial cells), fibroblasts, myocytes, mast cells, lymphoid cells, and macrophages. It has been proven that TNF- $\alpha$ plays a major role in neuroinflammation-mediated cell death in $\mathrm{PD}^{[7]}$ and in mouse models of $\mathrm{PD}^{[8]}$.

In the MPTP (1-methyl-4-phenyl-1, 2, 3, 6-tetrahydropyridine) model of PD, inflammatory reactions have been determined $^{[9-11]}$ and elevated pro-inflammatory cytokines have been found ${ }^{[12-14]}$.

The neurotoxin MPTP induces a clinical syndrome close to PD and, thus, is widely employed as a PD model in experimental animals ${ }^{[15]}$. MPTP, as well as its active metabolite $\mathrm{MPP}^{+}$(1-methyl-4-phenylpyridinium), can induce an inflammatory response ${ }^{[16,17]}$ and the death of DN by apoptotic pathway in the substantia nigra pars compacta $(\mathrm{SNc})$ in mouse ${ }^{[18]}$. MPTP will preferentially produce an inflammatory process after an acute treatment $(4 \times 20 \mathrm{mg} / \mathrm{kg}$ i.p. every $2 \mathrm{~h}$ on one day) ${ }^{[19]}$ and neuronal cell death after a chronic treatment $(30 \mathrm{mg} / \mathrm{kg} / \text { day during } 5 \text { consecutive days })^{[18,20]}$. The MPTP mouse model of PD and MPP ${ }^{+}$cell exposure both lead to apoptosis and TNF- $\alpha$ release and offer a good model for in vivo and in vitro Parkinson's studies.

The diagnosis of PD relies on a neurological exam based on the patient's history and physical examination. In addition to this, magnetic resonance imaging (MRI) and positron emission tomography (PET) scans can be useful to exclude other pathologies. However, these methods are not able to detect the early stages of the pathology.

The aim of this work was thus to study new vectorized contrast agents for early MRI detection of PD injured areas. These specific contrast agents are linked to peptides that show affinity for special molecular targets abundant in or specific to the injured areas of some pathology. In this work, two peptides selected by the phage display method were linked to iron oxide nanoparticles and Gd-DTPA (gadolinium-diethylenetriamine pentaacetic acid): 2C-peptide for MRI detection of inflammation ${ }^{[21]}$ and R826-peptide for apoptosis detection ${ }^{[22]}$ in a mouse model of PD.

\section{Material and methods}

\subsection{Animals}

Adult male mice C57BL/6JOlaHsd of 10-12 weeks old (Harlan Laboratories B.V.; The Netherlands) were used for histological $(\mathrm{n}=12)$ and MRI studies $(\mathrm{n}=14)$. Wistar Han newborn rat pups of 1-3 days old (Harlan Laboratories B.V.; The Netherlands) were used for cell cultures ( $\mathrm{n}=90$ for histological studies and $\mathrm{n}=51$ for relaxometric and luminescence assays). 
All animals were housed in plastic cages under a 12-h light/12-h dark cycle and had free access to food and water. Ambient temperature was maintained at $25 \pm 2^{\circ} \mathrm{C}$. Animals were maintained and treated in compliance with the guidelines specified by the Belgian Ministry of Trade and Agriculture (agreement: LA1500020).

\subsection{MPTP and MPP ${ }^{+}$treatment}

In the present study, MPTP was used to simulate PD on adult mice for ex vivo and in vivo studies. On cell cultures, MPP is preferred to simulate cell damage occurring in PD.

\subsection{1 $\mathrm{MPP}^{+}$treatment}

For immunocytochemistry, cell cultures were treated during $24 \mathrm{~h}$ with $30 \mu \mathrm{M}$ of $\mathrm{MPP}^{+}$. For apoptosis detection by caspase Glo $^{\circledR} 3 / 7$ and NMR measurements, cells were incubated during $24 \mathrm{~h}$ with $1 \mathrm{mM}$ of $\mathrm{MPP}^{+}$.

\subsubsection{MPTP treatment}

For inflammation studies, adult mice received an acute MPTP treatment (MA) consisting of 4 i.p. injections of MPTP-HCl (Sigma-Aldrich, Belgium) every $2 \mathrm{~h}(20 \mathrm{mg} / \mathrm{kg}$ body weight per injection) on the same day. Histological and MRI assessments were performed the next day after the injections.

For apoptosis studies, adult mice received a chronic MPTP treatment consisting of a daily injection of $30 \mathrm{mg} / \mathrm{kg}$ MPTP-HCl during 5 consecutive days. Assessments were performed on the last day of injection.

\subsection{MRI contrast agents}

In the present study, two types of contrast agents were used. The nanoparticles were preferred on cell cultures and histological sections since the iron they contain can be detected by Prussian blue method. PEG-USPIO used for cell cultures experiments were prepared as described by Burtea et al. ${ }^{[23]}$. Briefly, $0.503 \mathrm{~g}$ of aminoPEG750 and $0.327 \mathrm{~g}$ of EDCI were added to $15 \mathrm{ml}$ of nanoparticles $([\mathrm{Fe}]=0.175 \mathrm{~mol})$ and the reaction was stirred during $17 \mathrm{~h}$. The mixture was ultrafiltrated on a $30 \mathrm{kD}$ membrane to remove low-molecular material.

For in vivo experiments, Gd-DTPA was used because of its small size ${ }^{[24,25]}$, allowing extravasation, which is critical in the context of a leakage of the contrast agent across the disrupted BBB.

\subsection{Midbrain cell culture}

Ventral midbrain (VM) neurons and cortical cells were obtained from day 1-3 days old rats. Cells were dissociated and cultured on a glial monolayer, as previously described ${ }^{[26-28]}$. Briefly, the cerebral cortex was dissected in ice cold HBSS (Hanks Balanced Salt Solution)-glc $0.6 \%$ buffer solution and then dissociated with a $20 \mathrm{U} / \mathrm{ml}$ papain solution at $37^{\circ} \mathrm{C}$ followed by a manual trituration. Cells were plated at about 80,000 to 100,000 cells per well and with a density of $1,000,000$ cells $/ \mathrm{ml}$ onto a poly-L-lysine-coated glass coverslip in a 12-wells plate. Mitotic inhibition of glial cells was performed with FDU (5-fluorodeoxyuridine) solution ${ }^{[29]}$ when they reached a density of $70 \%$.

After 2 weeks, VM neurons were plated onto the glial monolayers. $24 \mathrm{~h}$ prior to plating, the glial growth medium was removed and serum-free Neurobasal medium (Invitrogen, Belgium) was added to each dish following two rinses with serum free Neuronal medium.

The midbrain was dissected and dissociated following the same procedure as for glial cells and plating 200,000 cells per well. One hour after plating, GDNF (Glial cell line-derived neurotrophic factor) was added to each well to promote DN survival ${ }^{[30,31]}$. The day after plating, glial cell division was inhibited with FDU and cells were maintained at $37^{\circ} \mathrm{C}$ in $5 \%$ $\mathrm{CO}_{2}$ during at least 9 days before $\mathrm{MPP}^{+}(30 \mu \mathrm{M}$ during $24 \mathrm{~h})$ treatment. 
For NMR measurements on cells incubated with nanoparticles and apoptosis detection by Caspase-Glo ${ }^{\circledR} 3 / 7$ in luminescence, the VM was dissected and dissociated as described above. Mesencephalic cells were directly incubated during $24 \mathrm{~h}$ with $1 \mathrm{mM}$ of $\mathrm{MPP}^{+}$neurotoxin and maintained at a density of 1 million cells per $5 \mathrm{ml}$ of Neurobasal medium to promote DN survival.

\subsection{Immunodetection of cell death and inflammation in cell cultures}

\subsubsection{Tyrosine hydroxylase detection}

Dopaminergic cells were detected on VM cultures by an anti-TH (tyrosine hydroxylase, a characteristic enzyme of DN) antibody. Cells were first fixed with $4 \%$ formaldehyde after washing and incubated for $1 \mathrm{~h}$ with the polyclonal anti-TH antibody (1:1,000, Abcam, France). Cells were then incubated for $1 \mathrm{~h}$ with a secondary antibody (1:50; goat anti-rabbit IgG; Vector Labs, Belgium) and for 30 minutes with the avidin-biotin horseradish-peroxidase complex (ABC-Elite kit, Vector Labs, Belgium) before DAB (diaminobenzidine, Sigma-Aldrich, Belgium)/Luxol fast blue staining. For immunofluorescence, cells were treated in the same way except that they were incubated for $1 \mathrm{~h}$ with a higher concentration of anti-TH antibody (1:800) and the secondary antibody was coupled with Texas Red fluorochrome (Invitrogen, Belgium). Cell slides were mounted with DAPI (4', 6'-diamidino-2-phenylindole) media before visualization.

\subsubsection{Apoptosis detection by biotinylated-annexin V}

After removal of the culture medium and subsequent washing, cells were incubated for 5 minutes with $0.06 \% \mathrm{H}_{2} \mathrm{O}_{2}$ and then for $1 \mathrm{~h}$ with biotinylated-annexin $\mathrm{V}$. Cells were then fixed in $4 \%$ formaldehyde after washing and incubated for 30 minutes with ABC-Elite kit. Staining was performed with DAB and Luxol fast blue. All incubations and washings were performed in a calcium/glucose buffer solution.

\subsubsection{Apoptosis detection with an ApopTag ${ }^{\circledR}$ Peroxidase In Situ oligo Ligation (ISOL) apoptosis detection kit}

The ISOL method uses T4 DNA ligase to specifically ligate DNase I-type ends to biotin-labeled hairpin oligonucleotides. This method allows for the localization of labeled oligonucleotides restricted to areas of chromatin characteristic of apoptotic nuclei.

For this method, cells were immediately fixed in $4 \%$ formaldehyde before quenching endogenous peroxidase with $0.5 \%$ $\mathrm{H}_{2} \mathrm{O}_{2}$. Cells were then incubated with DNA ligase enzyme for up to $16 \mathrm{~h}$ in equilibration buffer. After washing, cells were incubated for 30 minutes with streptavidin-peroxidase before staining with DAB and counterstaining with Luxol fast blue.

Stained nuclei were then counted using the Image J analysis software. Cell pixels are separated from background pixels by global thresholding, producing a binarized image that shows black cells on a white background. Clustered cells are then separated from each other by watershed segmentation. Finally, artifacts such as staining residues are discarded by removing objects smaller than 10 pixels and larger than 60 pixels.

\subsubsection{Apoptosis detection with the fluorescent-labeled NST-729 Aposense}

Aposense is a novel class of low molecular weight probes, developed for imaging of apoptosis in vivo. The ability of NST-729 to cross the blood brain barrier (BBB) and detect apoptotic cells in vivo has been demonstrated ${ }^{[32]}$. For the present study, NST-729 was synthesized in our laboratory according to the method described by Shirvan et al. (2009) for fluorescence detection of apoptotic cells in midbrain culture. Cells were incubated for 20 minutes with Aposense NST-729 in the dark after rinsing. Cells were then fixed with $4 \%$ formaldehyde before mounting in a DAPI medium. The same protocol was used for co-localization with TH-positive neurons except that cells were first incubated with the TH primary antibody followed by incubation with a Texas red-conjugated secondary antibody. 


\subsubsection{TNF-a detection in cell culture}

Cells were first fixed with $4 \%$ formaldehyde after washing and incubated overnight with the polyclonal TNF- $\alpha$ antibody (Abcam, France). The next day, cells were incubated for $1 \mathrm{~h}$ with a secondary antibody (1:50; goat anti- rabbit IgG; Vector Labs, Belgium) and for 30 minutes with the ABC-Elite kit before DAB/Luxol staining. For immunofluorescence, cells were treated in the same way except that the secondary antibody was coupled with a Texas red fluorochrome and cell slides were mounted with a DAPI medium before visualization.

\subsubsection{Apoptosis and inflammation detection by peptide-vectorized nanoparticles in cell cultures}

Detection of both inflammation and apoptosis by peptide-vectorized nanoparticles was performed with a similar protocol. Cells were first incubated for 15 minutes with nanoparticles at a concentration of $8 \mathrm{mM}$ each (PEG-USPIO, PEG-USPIO-2C and PEG-USPIO-R826; $6.6 \times 10^{14} \mathrm{NP} / \mathrm{ml}$ ) for $\mathrm{MPP}^{+}$treated and untreated cells, and fixed with $4 \%$ formaldehyde. Iron oxide nanoparticles were revealed by the Prussian blue staining method that colors iron in blue. Cells were finally counterstained in a pink-red color with eosin. All incubations and washings were performed in a calcium/glucose buffer solution.

\subsection{Quantification of activity of caspases 3 and 7 in MPP $^{+}$-treated mesencephalic cells}

The caspases 3 and 7 activities were evaluated by the Caspase-Glo ${ }^{\circledR} 3 / 7$ Assay (Promega, Belgium) on $\mathrm{MPP}^{+}$-treated and untreated cells. This kit is based on the cleavage of the DEVD sequence of a luminogenic substrate by the caspases 3 and 7 resulting in a luminescent signal. Caspase activities were measured $1 \mathrm{~h}$ and $2 \mathrm{~h}$ after incubation with the reactive solution kit.

\subsection{NMR relaxometric assay of apoptosis and inflammation targeting by iron oxide nanoparticles}

After $24 \mathrm{~h}$ of $\mathrm{MPP}^{+}$treatment, 1,000,000 cells $/ \mathrm{ml}$ were incubated for $30 \mathrm{~min}$ with $8 \mathrm{mM}$ of iron oxide nanoparticles (PEG-USPIO, PEG-USPIO-R826 and PEG-USPIO-2C) and resuspended in $2 \%$ gelatin after several washings in a calcium/glucose buffer solution. After resuspension in $200 \mu$ gelatin, cells were maintained on ice to allow rapid solidification of gelatin and avoid cell sedimentation. Apoptosis and inflammation targeting were assayed by NMR relaxometry at $37^{\circ} \mathrm{C}\left(\mathrm{T}_{2}\right.$ relaxation time measurements using a CPMG sequence with an echo time of $\left.1 \mathrm{~ms}\right)$ on a Bruker minispec $60 \mathrm{MHz}$ (Bruker, Karlsruhe, Germany). Relaxation rate values $\left(\mathrm{R}_{2}=1 / \mathrm{T}_{2}\right)$ were obtained for MPP $\mathrm{MP}^{+}$treated cells and untreated cells both incubated with iron oxide nanoparticles. Normalized $R_{2}\left(R_{2} N o r m\right)$ values were obtained by subtracting the $\mathrm{R}_{2}$ values of non-incubated cells from those of incubated cells.

\subsection{Immunodetection of TH-positive neurons and inflammation on brain section}

One day after MPTP treatment, mice were sacrificed and decapitated for brain removal. Brains underwent a $24 \mathrm{~h}$ fixation in $4 \%$ paraformaldehyde (PAF) for TNF- $\alpha$ detection and a $48 \mathrm{~h}$ fixation in an aqueous Bouin's fluid (75 $\mathrm{ml}$ of picric acid, $20 \mathrm{ml}$ of $40 \%$ formaldehyde and $5 \mathrm{ml}$ of acetic acid solution) for TH detection. They were then embedded in paraffin according to standard procedure after dehydration by several alcohol and butanol soakings. The organ was thus embedded in paraffin according to standard procedures. Midbrain sections of 7-micrometers thickness (10 sections per brain/mouse through the VM) were incubated in $2 \% \mathrm{H}_{2} \mathrm{O}_{2}$ (in 1M PBS) for $5 \mathrm{~min}$ to abolish endogenous peroxidase activity. After washing, sections were incubated with a casein solution for $1 \mathrm{~h}$ in order to prevent unspecific protein binding. Detection of TH-positive neurons for midbrain localization and inflammation was achieved with a polyclonal antibody to TH (Abcam, France) and TNF- $\alpha$ (Abcam, France), respectively. After incubation with the primary antibody, $1 \mathrm{~h}$ for TH and overnight for TNF- $\alpha$, sections were rinsed and incubated for $1 \mathrm{~h}$ with a goat anti-rabbit secondary antibody (Vector labs, Belgium). 
Sections were then incubated with the ABC-Elite kit for $30 \mathrm{~min}$. For visualization of peroxidase activity, sections were incubated for 5-15 min (depending on the primary antibody used) with DAB and $0.06 \% \mathrm{H}_{2} \mathrm{O}_{2}$. Sections were then counterstained with Luxol fast blue before mounting.

\subsection{Inflammation detection by the peptide 2C-linked iron oxide nanoparticles on brain section of MPTP-treated mice}

Inflammation detection by the peptide $2 \mathrm{C}$-linked iron oxide nanoparticles was performed on paraffin embedded sections of brain tissue collected one day after the last injection of MPTP as described above. Brain sections were incubated with the peptide linked iron oxide nanoparticle for 15 minutes and counterstained after several washings with an eosin solution. Iron was stained by the classical Prussian blue method.

\subsection{Anesthesia and surgical preparation for MRI}

For the MRI study, healthy and MPTP-treated mice were divided into 2 groups: in the first group, mice were injected with the Gd-DTPA contrast agent and the second group with the Gd-DTPA linked to the 2C peptide (Gd-DTPA-2C). In the beginning of the study, each group included 6 mice. Unfortunately, results were collected from a smaller number of mice because of mortality induced by the acute MPTP treatment combined with a major surgery and anesthesia. For the homogeneity of results, only mice that survived were considered: 2 mice for the MPTP-treated mice group injected with Gd-DTPA-2C, 3 mice for the MPTP-treated mice group injected with Gd-DTPA, 3 mice for the healthy mice group injected with Gd-DTPA-2C and 6 mice for the healthy mice group injected with Gd-DTPA. An intra-carotid injection of hypertonic mannitol was given to disrupt the BBB and allow delivery of contrast agents to brain tissue.

The intra-carotid injections required a surgical preparation of the mice. First, mice were anesthetized with an i.p. injection of pentobarbital solution $(0.01 \mathrm{ml} / 10 \mathrm{~g}$ body weight). The skin of the neck was incised and removed after disinfection. The right common carotid artery (CCA) and trachea were exposed by separation of muscles of the carotid muscular triangle. The CCA was elevated with a small cotton ball of 3-4 $\mathrm{mm}$ in diameter and ligatured with 2 knots in its proximal and distal extremities. Before injection, the silk suture under the proximal part of the CCA was tightly tied while the second ligature under the CCA distal to the injection was loosely tied.

Contrast agents $(0.3 \mathrm{mmol} / \mathrm{kg}$ of Gd-DTPA or Gd-DTPA-2C) and $25 \%$ mannitol solutions were injected with a $31 \mathrm{G}$ needle inserted between the 2 knots. Immediately after the last injection, the second ligature was tightly tied and the cotton ball was removed. MR imaging was performed immediately after the Gd-DTPA/Gd-DTPA-2C injection and mice were observed during $2 \mathrm{~h}$.

\subsection{MR imaging of inflammation on MPTP-treated mice}

MR imaging was performed on a $7 \mathrm{~T}$ horizontal scanner (Pharmascan, Bruker, Karlsruhe, Germany). Coronal $\mathrm{T}_{1}$-weighted spin echo images of $1 \mathrm{~mm}$ thickness were collected with the following parameters: repetition time (TR): $300 \mathrm{~ms}$, echo time (TE): $12 \mathrm{~ms}$, number of averages (NA): 6, 5 slices, acquisition of $5 \mathrm{~m} 45 \mathrm{~s}$, matrix: $256 \times 256$, field of view (FOV): $2.74 \mathrm{~cm}$ (in-plane resolution of $110 \mu \mathrm{m} / \mathrm{pixel}$ ).

Axial $\mathrm{T}_{1}$-weighted rapid acquisition spin echo images were collected with the following characteristics: TR: $450 \mathrm{~ms}$, TE: $17 \mathrm{~ms}$, NA: 6, 5 slices, acquisition of $5 \mathrm{~m} 45 \mathrm{~s}$, matrix: $256 \times 256$, FOV: $2.3 \mathrm{~cm}$, slice thickness: $1 \mathrm{~mm}$ (in-plane resolution: $90 \mu \mathrm{m} / \mathrm{pixel})$.

The relative signal intensity enhancement (SE) of the region of interest corresponding to the SNc area was calculated with the following equation (see Figure 14): 


$$
\frac{(R I 1 / R I 2)_{\text {post-injection }}-(R I 1 / R I 2)_{\text {pre-injection }}}{(R I 1 / R I 2)_{\text {pre-injection }}} \times 100 \%
$$

where $R I 1$ is the ratio between the signal intensity of the SNc and the signal intensity of the reference (Gd-DTPA $25 \mu \mathrm{M}$ ) and RI2 is the ratio between the signal intensity of a random region in the middle of the injected cerebral hemisphere and the signal intensity of the reference.

Spin echo images were acquired before and during $2 \mathrm{~h}$ after injections for each mouse (untreated and MPTP-treated mice) and the SE was calculated at 10, 25, 45, 75, 90 and 120 min after injections.

\section{Results and discussions}

\subsection{Apoptosis detection in VM cultures}

The apoptotic process is characterized by several events. Among them, the translocation of PS on the outer leaflet of the plasma membrane is a surface change common to many apoptotic cells and can serve to detect apoptosis in many situations. In the present study, we used this mechanism to detect apoptosis in cultured cells.

In order to confirm the death pathway caused by the $\mathrm{MPP}^{+}$treatment, several tests were performed in mesencephalic cell cultures.

\subsubsection{Apoptosis detection by biotinylated-annexin $\mathbf{V}$ and the ApopTag method}

Annexin V is a protein showing a high affinity for PS and is therefore able to link to the externalized PS of apoptotic cells. In this part of the work, biotinylated annexin V was used to visualize apoptotic cells in VM cultures ( $\mathrm{n}=3$ cultures) treated with the $\mathrm{MPP}^{+}$neurotoxin.

Twenty-four hours after $\mathrm{MPP}^{+}$treatment, apoptotic cells were easily found in neuronal cell cultures (see Figure 1a, 1b). Cell death was found at several stages of the apoptotic process with neurons showing some reduced processes or lacking them. Untreated cultures showed unstained neuronal cells with a normal structure.

Figure 1. Apoptosis detection by biotinylated annexin $\mathrm{V}$ and the ISOL (Apoptag ${ }^{\circledR}$ ) method in VM cultures. $(a, b)$ The biotinylated annexin $\mathrm{V}$ recognizes PS translocated to the external membrane leaflet during the apoptosis process. $\mathrm{MPP}^{+}$-treated cultures showed apoptotic neurons at the end and early stages of the apoptotic process (brown color). The neurons shown above $(\mathrm{a}, \mathrm{b})$ are losing their processes, as compared to healthy TH-positive neurons (d). (c, e) The ApopTag ${ }^{\circledR}$ Peroxidase kit uses the TUNEL method to detect apoptotic cells in situ by labeling and detecting DNA strand breaks. Apoptotic nuclei are then visualized by DAB staining in the $\mathrm{MPP}^{+}$-treated cultures (black arrows). Untreated cell cultures (f) contained healthy neurons and showed no DAB staining. Scale bar: $20 \mu \mathrm{m}$.

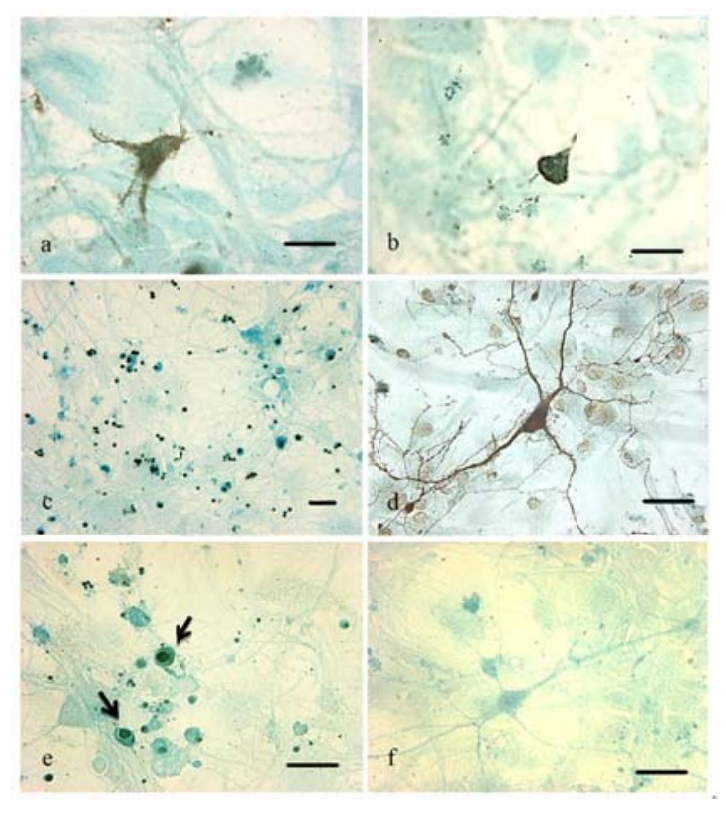


Apoptosis was also detected with the ISOL (Apoptag) method based on DNA fragmentation, which is another molecular characteristic of apoptotic cells. In $\mathrm{MPP}^{+}$-treated cultures, more cells showed stained nuclei, as compared to untreated cultures (see Figure $1 \mathrm{c}-\mathrm{f}$ ). Furthermore, $\mathrm{MPP}^{+}$-treated cultures showed very few neurons with a healthy morphology and many stained cells showed a loss of processes, while untreated cultures contained neurons with a healthy morphology and long processes.

The number of apoptotic cells was assessed on both $\mathrm{MPP}^{+}$-treated and untreated cell cultures by counting stained nuclei on 5 random microscopic fields per cell culture slide $\left(\mathrm{n}=6\right.$ cultures for each $\mathrm{MPP}^{+}$-treated and untreated cells). Apoptotic cells were more numerous on $\mathrm{MPP}^{+}$-treated cell cultures with an average number of $34.2 \pm 3.1$ Apoptag positive cells $(P<.01$, Student's $t$-test). The average value for untreated cells was $8.3 \pm 1.6$ (see Figure 2$)$.

These results are concurrent and both confirm that $\mathrm{MPP}^{+}$leads to an apoptotic pathway on midbrain cultures.

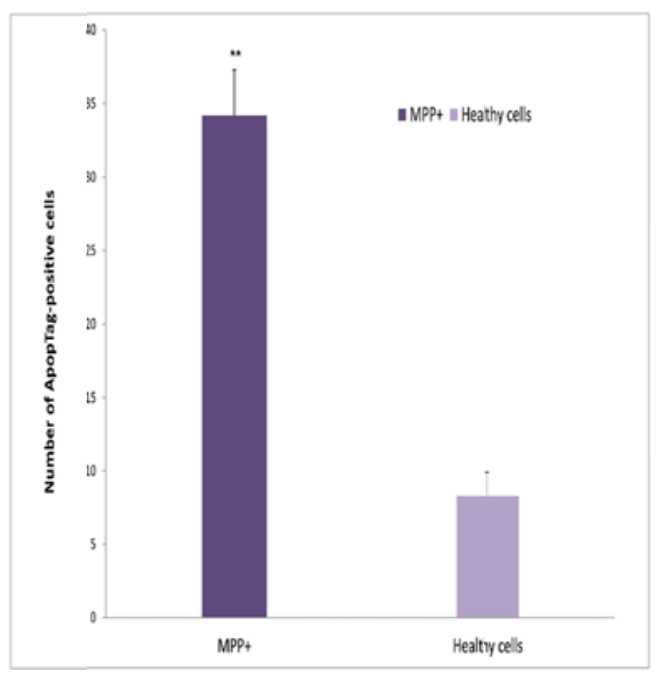

Figure 2. Evaluation of the Apoptag-positive cell number on $\mathrm{MPP}^{+}$-treated and untreated cell cultures. Cells treated with $\mathrm{MPP}^{+}$substrate showed a greater average number of stained nuclei than untreated cell cultures, suggesting that $30 \mu \mathrm{M}$ $\mathrm{MPP}^{+}$can induce a significant increase of apoptotic activity in midbrain cell cultures (**P<.01, Student's $t$-test).

\subsubsection{Co-localization of TH-positive neurons and apoptosis}

In order to confirm that $\mathrm{MPP}^{+}$treatment leads to a specific cell death of DN by apoptosis, a co-localization study was performed between TH-positive DN and apoptosis. For this study, the NST-729 Aposense molecule was used to detect apoptotic cells and DN was detected with an anti-TH antibody. Cell nuclei were counterstained by a DAPI solution, which is a well-known blue fluorescent probe linking DNA.

In untreated cultures $(n=3)$, TH-positive neurons showed a classical healthy morphology with processes, and their nuclei had a uniform shape typically found in healthy cells (see Figure 3e, 3h). Furthermore, untreated cells do not show staining by the NST-729 Aposense molecule suggesting that there was no cell death in these cultures.

On the contrary, the nuclei of $\mathrm{MPP}^{+}$-treated cells ( $\mathrm{n}=3$ cultures) had an aberrant morphology: condensed, chopped, and smaller than healthy nuclei (see Figure 3c). TH-positive neurons seem to have lost their neurite processes when compared to healthy cells (see Figure 3a).

NST-729 stained numerous MPP ${ }^{+}$-treated cells and this staining was concordant with the TH staining (see Figure 3a, 3b), which proved that $\mathrm{MPP}^{+}$leads to an apoptotic pathway of DN in midbrain culture. 

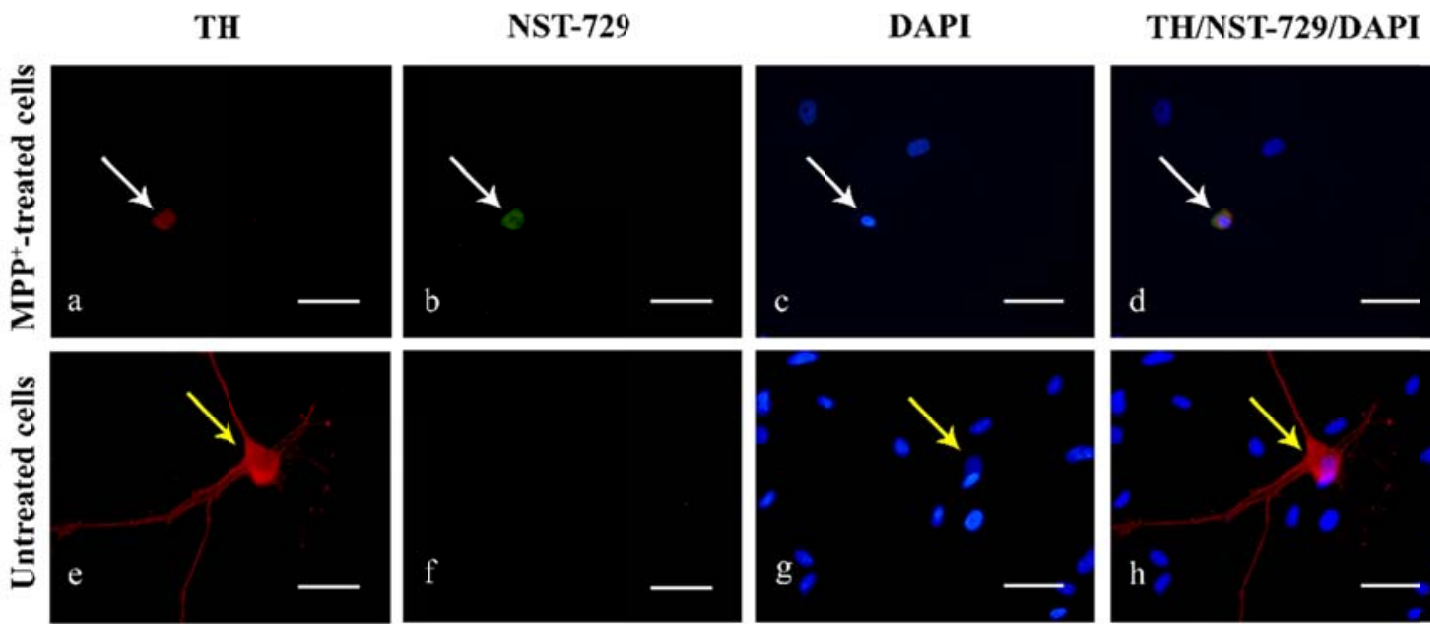

Figure 3. TH positive neurons and NST-729 labeled neurons for apoptosis/DN co-localization. $\mathrm{MPP}^{+}$-treated cultures showed TH-positive neurons (a), without neurite and with a condensed cytoplasm, and NST-729 labeled neurons (b) corresponding to the TH staining. These cells had typical apoptotic nuclei (c) as compared to untreated cells that showed healthy ND (e), no apoptotic cells (f) and healthy nuclei (g). (d, h) The yellow color (d) revealed that TH, NST and DAPI co-localize. Untreated cells didn't show any yellow color and thus no co-localization (h). Scale bar: $50 \mu \mathrm{m}$. White arrows show apoptotic cells and yellow arrows show healthy cells.

\subsubsection{Apoptosis detection with the peptide-linked iron oxide nanoparticle in cell cultures}

The results presented above were all concordant in proving that $\mathrm{MPP}^{+}$triggers cell death by an apoptotic pathway in cultured cells. An iron oxide nanoparticle linked to a peptide selected by phage display for its affinity for apoptotic cells (PEG-USPIO-R826) was incubated with VM cultures. The PEG-USPIO-R826 nanoparticles were largely tested on control and apoptotic cells (Jurkat cells) in our laboratory ${ }^{[33]}$. VM cultures were treated or not with $\mathrm{MPP}^{+}$in the same way as for apoptosis detection tests and then incubated with the specific or non-specific iron oxide-based contrast agent. Only $\mathrm{MPP}^{+}$-treated cells were specifically targeted by the peptide-linked iron oxide nanoparticles colored in blue by the Prussian blue method (see Figure 4a). Untreated cell cultures did not show such staining (see Figure 4b). The non-specific iron oxide nanoparticle was not able to target apoptosis in either untreated or $\mathrm{MPP}^{+}$-treated cell cultures (see Figure 4c, 4d). This result suggested that apoptosis caused by $\mathrm{MPP}^{+}$treatment can be targeted by the peptide-linked iron oxide nanoparticles PEG-USPIO-R826.

Figure 4. Apoptosis detection with PEG-USPIO-R826. The specificity of the apoptosis-targeting iron oxide nanoparticles was tested on $\mathrm{MPP}^{+}$-treated $(\mathrm{n}=3)$ and untreated cells $(\mathrm{n}=3)$. Iron content was detected by the Prussian blue method which stains iron in blue. The specific contrast agent was largely found on $\mathrm{MPP}^{+}$-treated cell cultures (a) as compared to untreated cells (b). The non-specific contrast agent was also tested on $\mathrm{MPP}^{+}$-treated and untreated cell cultures in order to prove the specificity of PEG-USPIO-R826. Contrary to PEG-USPIO-R826, the PEG-USPIO was not able to target cells in either treated (c) or untreated (d) cultures. Scale bar: $50 \mu \mathrm{m}$.
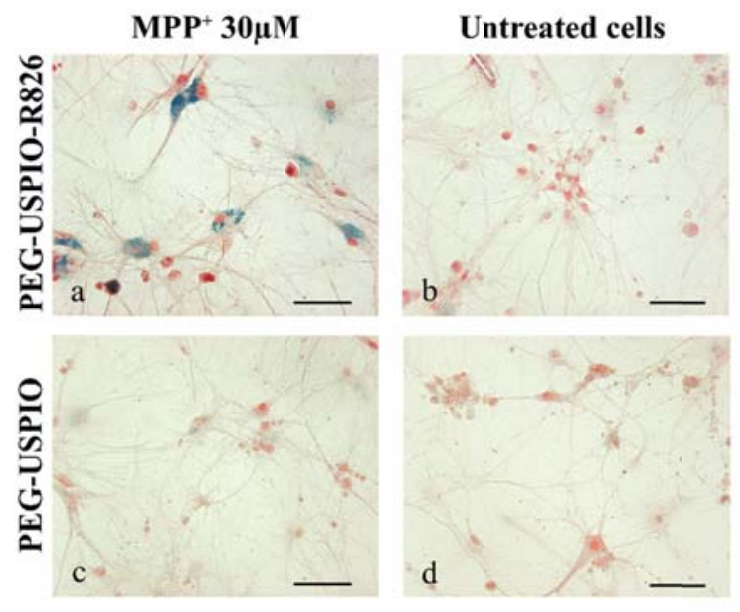


\subsubsection{Quantification of activity of caspases 3/7 in MPP ${ }^{+}$-treated mesencephalic cells}

Apoptosis caused by the $\mathrm{MPP}^{+}$treatment on mesencephalic cells was quantified by measuring the caspase $3 / 7$ activity in luminescence. Cells were treated with $1 \mathrm{mM} \mathrm{MPP}^{+}$during $24 \mathrm{~h}$ and caspase activity was measured $1 \mathrm{~h}$ and $2 \mathrm{~h}$ after mixing cells with the caspase-glo 3/7 reagent. Results showed that $\mathrm{MPP}^{+}$-treated cells had a higher caspases 3/7 activity than healthy cells (see Figure $5, \mathrm{n}=8$ cultures, $P<.05$, Student's $t$-test). The caspase activity of treated cells was significantly more elevated than that of healthy cells. After $2 \mathrm{~h}$ incubation, caspase activity began to decrease and the difference between treated and untreated cells became less marked $(P>.05$, Student's $t$-test).

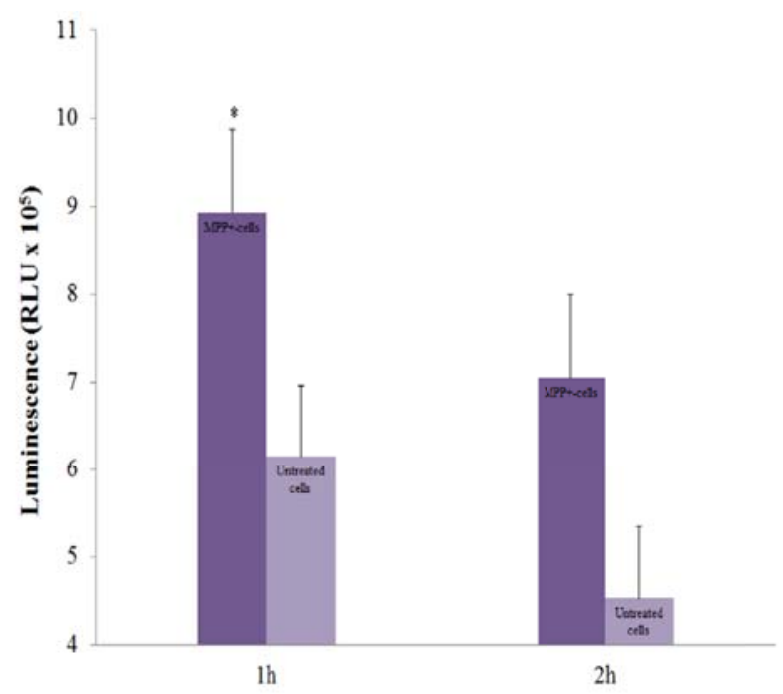

Figure 5. Evaluation of caspases $3 / 7$ activity on midbrain cell cultures. $\mathrm{MPP}^{+}$-treated cell cultures showed a significant activity of caspase $3 / 7$. Although untreated cells showed caspase activity, the difference between untreated and treated cells was significant after a $1 \mathrm{~h}$ incubation time $\left({ }^{*} P<.05\right.$, Student's $t$-test $)$.

\subsection{NMR relaxometric assay of apoptosis targeting by iron oxide nanoparticles}

After demonstrating apoptotic cell death on $\mathrm{MPP}^{+}$-treated cell cultures, NMR relaxometric assays were performed on both treated and untreated cells to evaluate R826 iron oxide nanoparticles as apoptosis targeting agents in the context of this PD model.

One million cells were incubated with the targeted (PEG-USPIO-R826) and untargeted iron oxide (PEG-USPIO) nanoparticles ( $n=4$ cultures).

The $\mathrm{R}_{2}$ value of $\mathrm{MPP}^{+}$-treated cultures incubated with targeted iron oxide nanoparticles was not significantly higher than those of $\mathrm{MPP}^{+}$-treated cells incubated with native plain iron oxide nanoparticles (see Figure $6 ; P>.05$, Student's $t$-test) or of healthy cells incubated with either targeted or untargeted iron oxide nanoparticles (see Figure $6 ; P>.05$, Student's $t$-test). However, ventral midbrain dissection does not allow exclusively collecting DN, which are the target of the MPP toxin. The assay was thus actually performed on dopaminergic and glial cells. Hence, there was possibly an insufficient number of DN in such a culture. It nevertheless allowed to observe the tendency for USPIO to be retained by MPP ${ }^{+}$-treated cultures to a greater extent when bound to the R826 peptide. Because of such results and inability to prove that cell death on MPTP-treated mice was apoptotic, R826 peptide was not linked to Gd-DTPA contrast agent for further ex vivo and in vivo studies. 


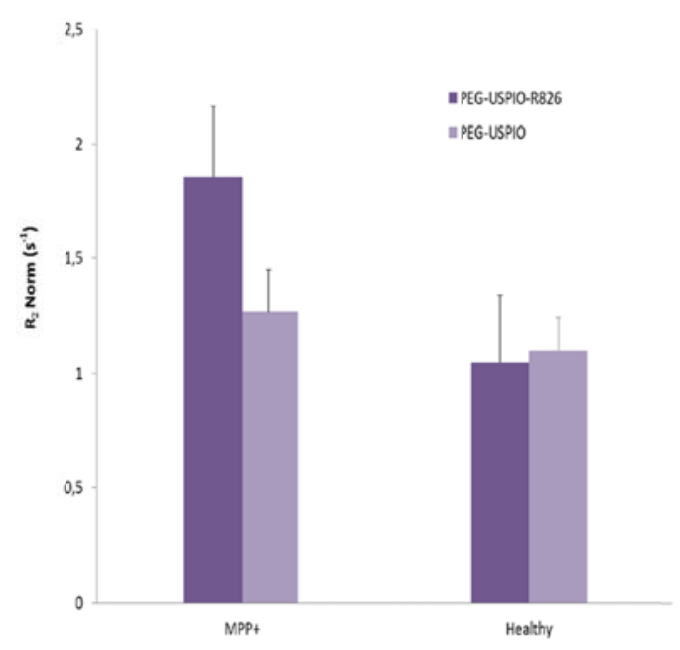

Figure 6. NMR relaxometric assay of apoptosis targeting by iron oxide nanoparticles. $\mathrm{MPP}^{+}$-treated cultures seemed to show a higher $R_{2}$ value after incubation with targeted iron oxide nanoparticles $(P>.05$, Student's $t$-test). Both treated and untreated cells incubated with untargeted iron oxide nanoparticles showed $R_{2}$ values similar to that of untreated cells incubated with targeted nanoparticles. These results did not allow to find a significantly greater retention of PEG-USPIO-R826 by MPP ${ }^{+}$-treated cells.

\subsection{Inflammation detection in VM culture}

\subsubsection{TNF-a detection in cultured mesencephalic cells by an anti-TNF-a antibody}

It is well known that $\mathrm{MPP}^{+}$is able to promote an inflammatory reaction and induces TNF- $\alpha$ release ${ }^{[34]}$ in dopaminergic cell cultures.

In order to confirm the presence of TNF- $\alpha$ and the inflammatory process on $\mathrm{MPP}^{+}$-treated VM cultures, immunodetection of inflammation was performed with an anti-TNF- $\alpha$ antibody. MPP ${ }^{+}$-treated cultures $(n=3)$ showed stained cells, which were not observed on untreated cultures $(\mathrm{n}=3)$. These results confirmed that an inflammatory process happens in cultured mesencephalic cells when treated with the $\mathrm{MPP}^{+}$neurotoxin (see Figure 7).

Figure 7. TNF- $\alpha$ detection on midbrain cell cultures. TNF- $\alpha$ was detected by an anti-TNF- $\alpha$ antibody on $\mathrm{MPP}^{+}$-treated cells (a: DAB staining, black arrows, and c: fluorescence, white arrow) but not in untreated cells (b). Scale bar: $50 \mu \mathrm{m}$.

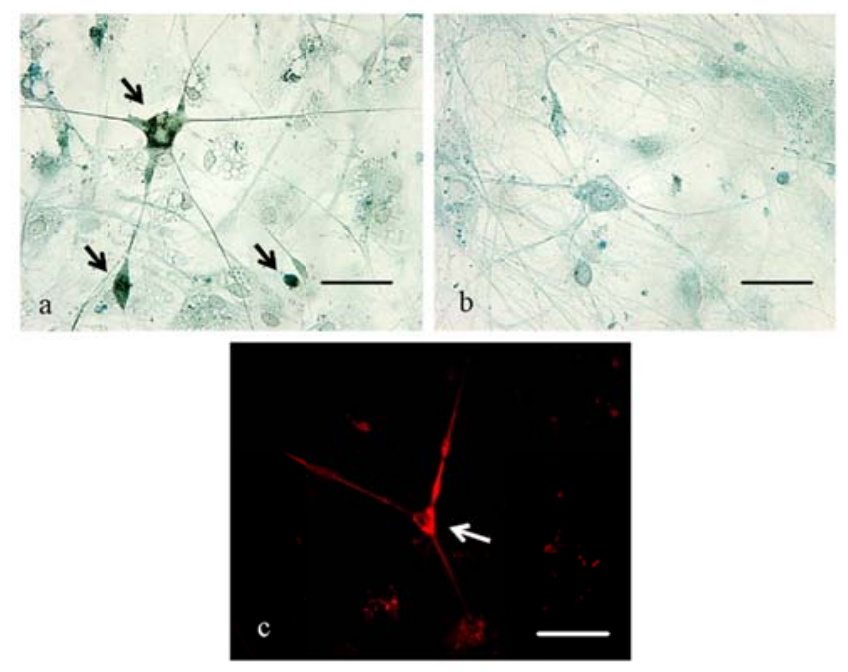




\subsubsection{TNF-a detection in cultured mesencephalic cells by the peptide-linked iron oxide nanoparticles}

The peptide $2 \mathrm{C}$ selected by phage display for its affinity to TNF- $\alpha$ was grafted in our laboratory to iron oxide nanoparticles for MRI targeting of inflammation. Initially, this specific contrast agent was tested on cultured mesencephalic cells $(n=3$ cultures) and detected by Prussian blue iron staining. The PEG-USPIO-2C seemed to target inflammation on $\mathrm{MPP}^{+}$-treated cells (see Figure 8a), as compared to untreated cells that showed no similar staining (see Figure 8b). No staining was found in either treated or untreated cells with the non-specific PEG-USPIO (see Figure 8c, 8d).

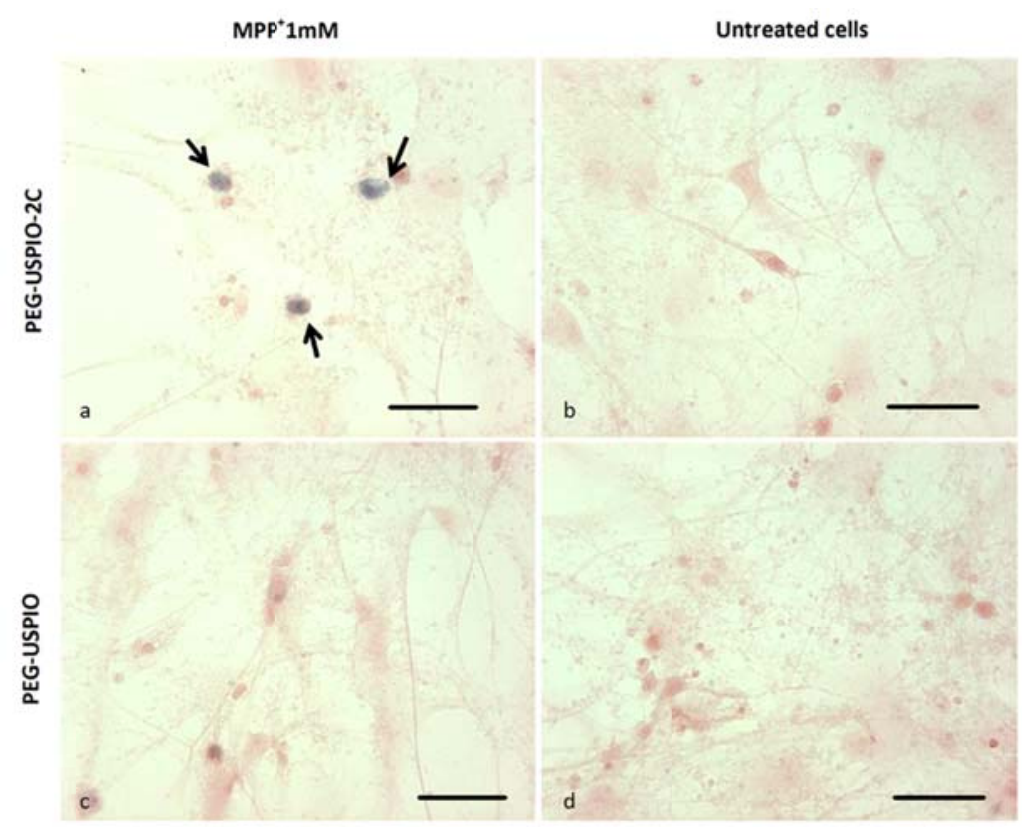

Figure 8. Inflammation detection with the specific PEG-USPIO-2C. MPP ${ }^{+}$-treated cells and untreated cells were incubated with both PEG-USPIO-2C and PEG-USPIO, revealed by the Prussian blue method. PEG-USPIO-2C was able to target TNF- $\alpha$ in the $\mathrm{MPP}^{+}$-treated cultures (a, black arrows). This targeting was not detected with the PEG-USPIO in either treated (c) or untreated (d) cultures. Furthermore, inflammation was not detected by PEG-USPIO-2C on the untreated culture (b). Scale bar: $50 \mu \mathrm{m}$.

\subsection{NMR relaxometric assay of inflammation targeting by iron oxide nanoparticles}

Like for apoptotic cells, NMR relaxometric assays were performed on both treated and untreated cells to evaluate the inflammation targeting by the TNF- $\alpha$-specific $2 \mathrm{C}$-linked iron oxide nanoparticles.

Cells were incubated with the targeted and plain iron oxide nanoparticles (PEG-USPIO-2C and PEG-USPIO, respectively) at a concentration of 1 million cells ( $n=5$ cultures).

$\mathrm{MPP}^{+}$-treated cultures showed a higher $\mathrm{R}_{2}$ value after incubation with the $2 \mathrm{C}$ conjugated iron oxide nanoparticles (see Figure 9; $P<.05$, Student's $t$-test). Both treated and untreated cells incubated with untargeted iron oxide nanoparticles showed $\mathrm{R}_{2}$ values similar to that of untreated cells with targeted nanoparticles. Relaxometry results suggest that a better interaction occurs between PEG-USPIO-2C and $\mathrm{MPP}^{+}$-treated cultures than with all the other analyzed cases, potentially reflecting a specific interaction between targeted nanoparticles and TNF- $\alpha$. 


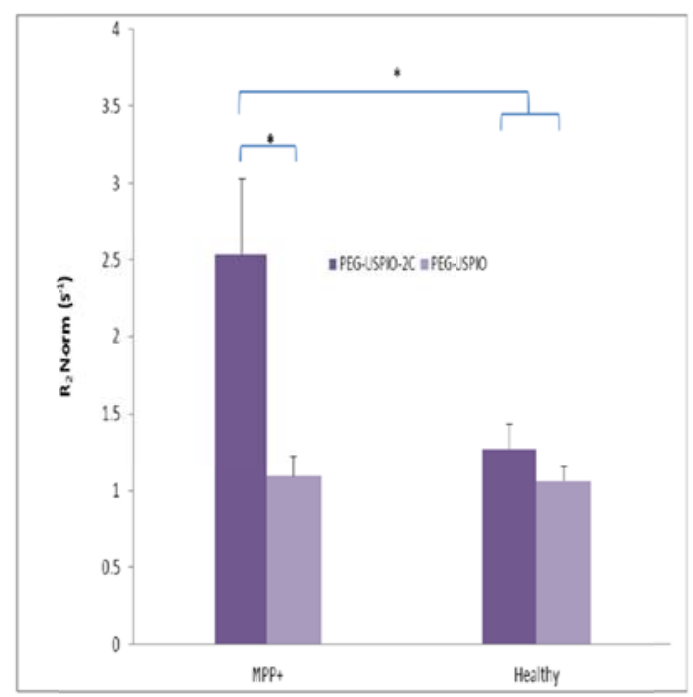

Figure 9. NMR relaxometric assay of inflammation targeting by iron oxide nanoparticles. Inflammation was detected on $\mathrm{MPP}^{+}$-treated and untreated cells by both $2 \mathrm{C}$ peptide vectorized iron oxide nanoparticles and plain nanoparticles. The assay was performed on 1 million cells. With such a cell concentration, the PEG-USPIO-2C seemed to be able to detect inflammation in $\mathrm{MPP}^{+}$-treated cells with a significantly higher affinity, as compared to untreated cells and to the unvectorized contrast agent $(*: P<.05$, Student's $t$-test).

\subsection{Immunohistochemical detection of inflammation on brain sections of MPTP-treated mice}

MPTP treatment is well known to promote inflammatory processes and to increase the expression of pro-inflammatory cytokines in $\mathrm{SNc}^{[35]}$. Inflammation was identified with an anti-TNF- $\alpha$ antibody on brain sections of MPTP-treated mice (see Figure 10a, 10c, 10d). The inflammatory process occurred in the mesencephalic region corresponding to TH-positive neuron areas of the SNc and VTA (ventral tegmental area) (see Figure $10 \mathrm{~b}$ ).
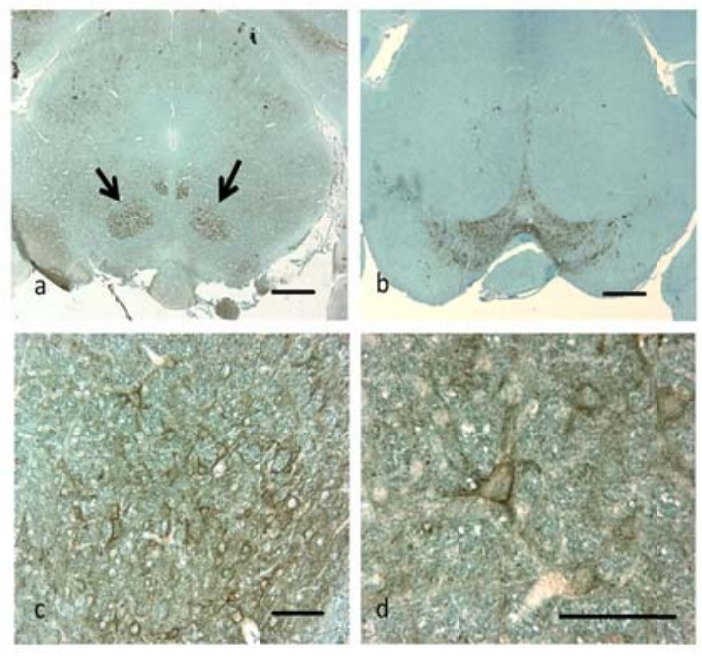

Figure 10. Immunohistochemical detection of inflammation with an anti-TNF- $\alpha$ antibody. Inflammation was detected on brain sections of acute MPTP-treated mice (black arrows, $n=6$ ) (a). The inflammation was located in the same region as TH-positive neurons $(b, n=6)$ suggesting that the inflammatory process caused by MPTP occurs mainly in the DN region. (c, d) Cellular localization of TNF- $\alpha$. Scale bar: $1 \mathrm{~mm}$ for (a, b); $100 \mu \mathrm{m}$ for (c, d). 


\subsection{Inflammation detection by the $2 \mathrm{C}$ peptide-linked iron oxide nanoparticles on brain sections of MPTP-treated mice}

The specificity of the $2 \mathrm{C}$ peptide-linked iron oxide nanoparticles was verified on brain sections of MPTP-treated mice $(n=6)$. Prussian blue staining showed a targeting of the mesencephalic region with the specific nanoparticles (see Figure 11a). This staining was located in the same area as those of TNF- $\alpha$ and TH staining (see Figure 11b). The result suggested a specific targeting of the $2 \mathrm{C}$ peptide-linked iron oxide nanoparticles to TNF- $\alpha$ on brain sections.
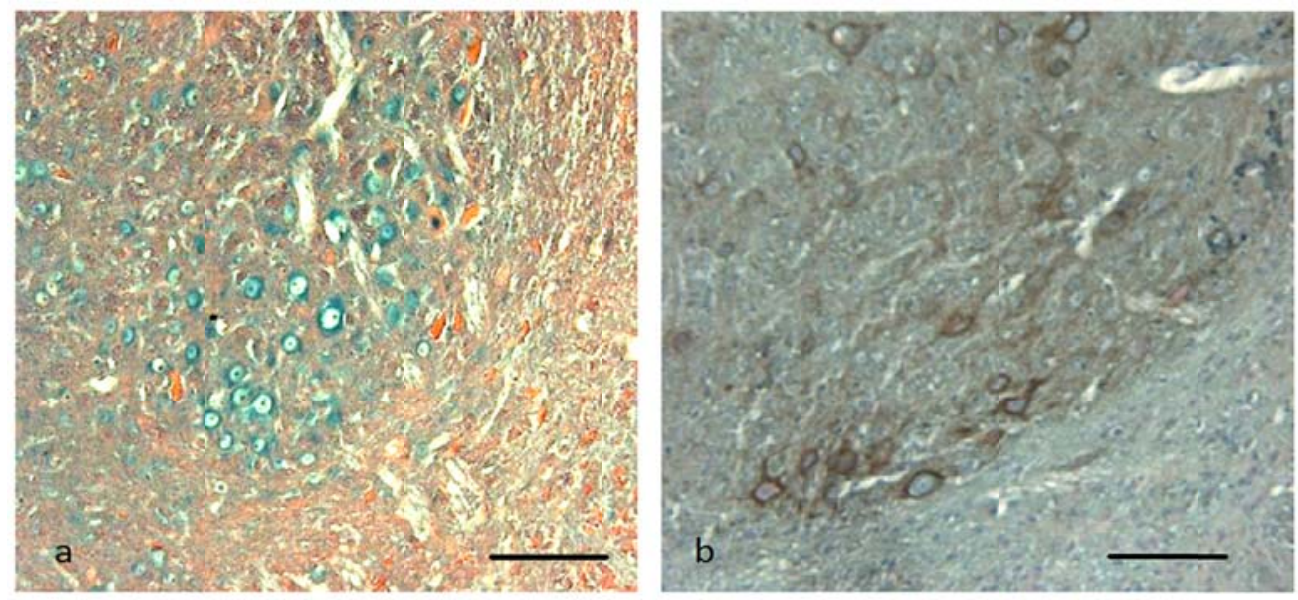

Figure 11. Inflammation detection by the $2 \mathrm{C}$ peptide-linked iron oxide nanoparticles on brain section of MPTP-treated mice. Detection of inflammation by the $2 \mathrm{C}$ peptide-linked iron oxide nanoparticles showed a similar staining (a) to that of TNF- $\alpha$ antibody (b). The staining was present in the mesencephalic region, similarly to TNF- $\alpha$ and TH staining. Scale bar: $100 \mu \mathrm{m}$.

\subsection{MR imaging of inflammation on MPTP-treated mice}

MPTP-treated mice injected with 2C linked-Gd-DTPA showed a SE increase in the region of interest $1 \mathrm{~h}$ after injection. MR images showed a positively contrasted moustache-shaped area (see Figure 12, white arrow) located in the SNc/VTA region (see Figure 13), suggesting a specific enhancement of signal intensity due to Gd-DTPA-2C.

Figure 12. MR imaging of inflammation on acute MPTP-treated mice (MA). Gd-DTPA and Gd-DTPA-2C were injected into the right carotid of healthy and MPTP-treated mice after a carotid injection of mannitol, which allows contrast agents to cross over the BBB and diffuse into brain tissue. Healthy mice injected with Gd-DTPA showed global signal intensity enhancement on the side of the injection although Gd-DTPA-2C seemed to cross the BBB inhomogeneously during the first minutes following the injection. MPTP-treated mice injected with Gd-DTPA-2C showed signal intensity enhancement in SNc $1 \mathrm{~h}$ post-injection. MR images suggest a specific targeting of inflammation by Gd-DTPA-2C on MPTP-treated mice (white arrow).

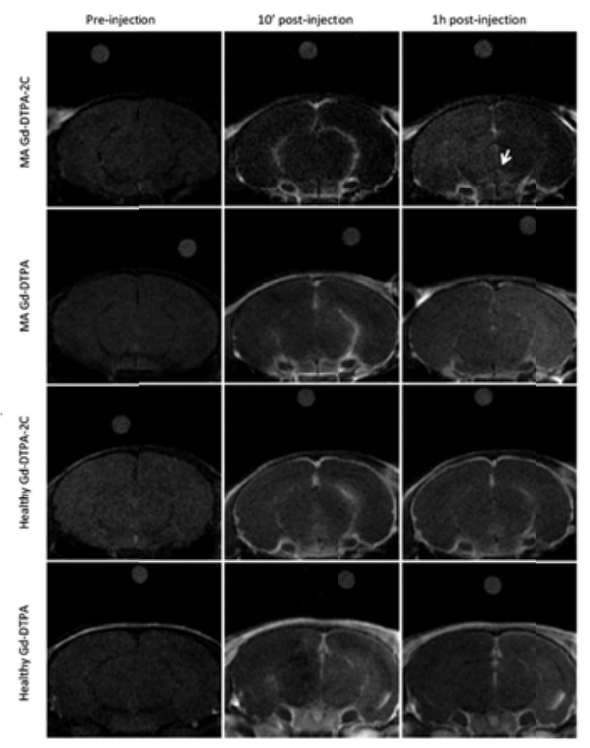



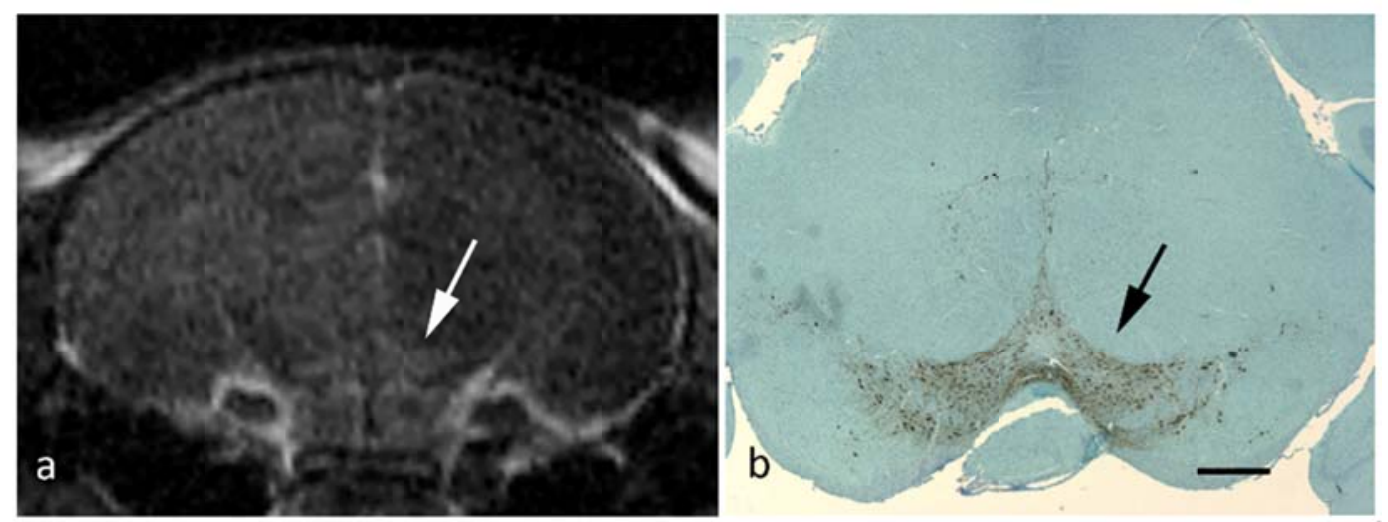

Figure 13. Comparison between MRI image showing targeting of inflammation in SNc and immunohistological localization of SNc. The specificity of Gd-DTPA-2C to TNF- $\alpha$ seems to allow Gd-DTPA to interact with inflamed SNc area, which was suggested by MRI observations (a). One hour post-injection, the region of interest (SNc, white and black arrows) became clearly apparent, showing the well-known typical moustache-shaped area of the SNc and corresponding to the TH-positive region detected by immunohistochemistry (b). Scale bar: $1 \mathrm{~mm}$.

SE reached a peak at $32 \%, 75$ minutes post-injection, and then decreased to a maintained value of $24 \%$ (see Figure 14).

MPTP-treated mice injected with untargeted contrast agent did not show any enhancement of signal intensity in the region of interest. SE values remained under $0 \%$ for $2 \mathrm{~h}$ (see Figure 14) between the SNc and the middle right hemisphere, which is represented in MR images by a global enhancement of signal intensity in the injected side of the brain (see Figure 12). These images did not show the characteristic shape of SNc as observed on images of MPTP-treated mice injected with targeted contrast agent, thus the right SNc did not show any specific targeting by the non-specific contrast agent and the signal intensity was globally enhanced in the right brain hemisphere like observed in healthy mice.

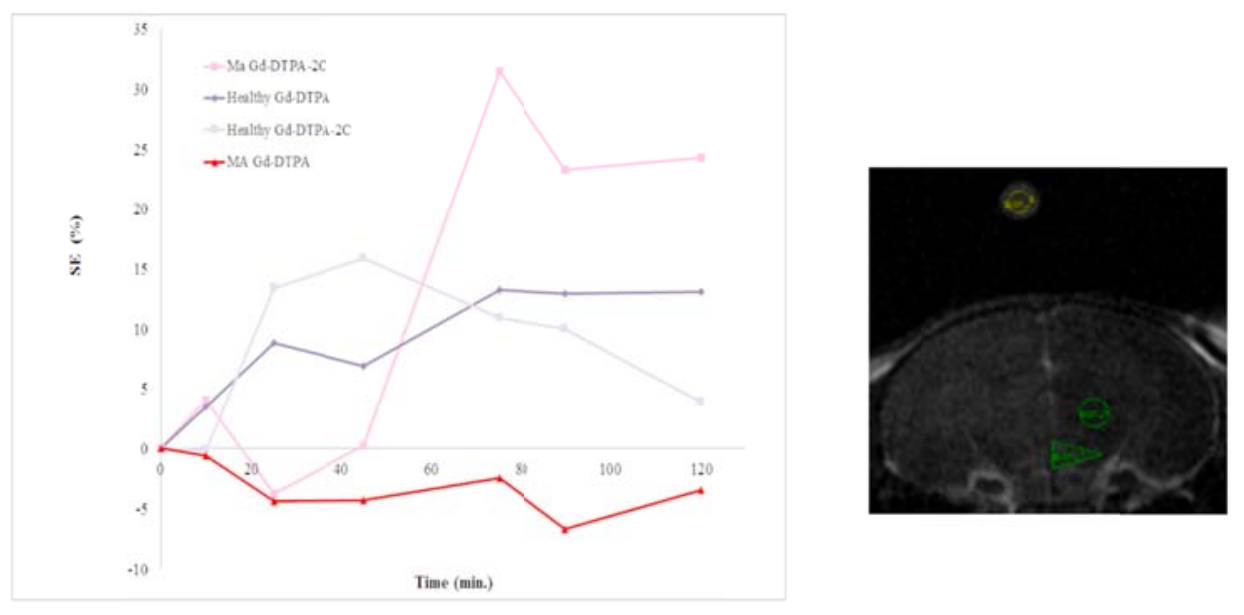

Figure 14. Evolution of relative signal intensity enhancement (SE) in the SNc region. SE of injected mice was calculated from signal intensity of the region of interest (SNc, represented by a triangle), a random region on the right hemisphere (represented by a green circle) and the Gd-DTPA reference (yellow circle). MPTP-treated mice (MA) injected with Gd-DTPA-2C first showed a decrease of SE in SNc, remaining in the range of the signal standard deviation measured in ROIs of previous time points, which subsequentely increased to reach a peak 75 minutes post-injection. Healthy mice injected with Gd-DTPA or Gd-DTPA-2C showed an increase of SE in SNc which is lower than for MPTP-treated mice injected with Gd-DTPA-2C. 
Healthy mice injected with Gd-DTPA and Gd-DTPA-2C did not show either the characteristic form of SNc. Healthy mice injected with Gd-DTPA-2C showed an intensity enhancement that rapidly decreased (see Figure 14), and those injected with Gd-DTPA maintained a SE value around 10\%-15\%.

The MR images suggest a possible interaction between the targeted contrast agent and TNF- $\alpha$ in the SNc after an acute MPTP treatment. The typical shape of SNc was only visible on MR images of MPTP-treated mice injected with Gd-DTPA-2C, which suggests the interaction of this contrast agent with TNF- $\alpha$ in a specific inflamed region in the brain. SE measurements show an increase of signal intensity in the region of interest $1 \mathrm{~h}$ after injections. Although SE also increased in healthy mice, MPTP-treated mice injected with the targeted contrast agent seem to have a higher SE value that did not decrease with time during our observation period.

\section{Conclusions}

$\mathrm{PD}$ is a common neurodegenerative disease that is not well understood yet and its diagnosis remains difficult. Molecular MRI offers a good opportunity to facilitate early detection of PD by the use of peptide-conjugated contrast agents.

Our laboratory develops peptide vectors that allow contrast agents to specifically target injured areas in idiopathic diseases. Peptide vectors are first identified by the phage display method and are then grafted to MRI contrast agents, such as iron oxide nanoparticles or Gd-DTPA.

With results obtained in vitro on cell cultures, ex vivo on histological brain sections, and in vivo on MR images, the present study suggests that peptide-conjugated contrast agents show specific targeting capabilities. PD was simulated on cell cultures by the well-known MPP+ neurotoxin and with its MPTP precursor in mice. Inflammation and apoptosis were first confirmed on VM cultures before testing specific contrast agents in vitro for the targeting of both inflammatory and apoptotic processes. PEG-USPIO-R826 and PEG-USPIO-2C seemed to be able to detect, respectively, apoptotic cells and inflammation in culture. The histological study confirmed inflammation and seemed to confirm inflammation targeting by PEG-USPIO-2C. Finally, the $2 \mathrm{C}$ peptide was grafted to Gd-DTPA, a smaller contrast agent, for in vivo MRI studies. Because histological assays could not allow us to detect an apoptotic process on chronic MPTP-treated mice, the specific R826 grafted contrast agent was not tested in vivo by MRI.

Preliminary in vivo MRI data collected on the acute MPTP mouse model suggested an interaction of Gd-DTPA-2C with the inflamed SNc area, which was not evident for MPTP-treated mice injected with Gd-DTPA, nor for healthy mice injected with Gd-DTPA and Gd-DTPA-2C. The region of interest (SNc, which is undergoing inflammation) became distinguishable from the surrounding tissue, appearing as the well-known typical moustache-shaped area, also corresponding to the TH-positive region detected by immunohistochemistry.

Collected experimental data seem to reflect the ability of specific contrast agents to detect a specific injured area in the brain of Parkinsonian mice. This report offers a new horizon of perspectives in the study and detection of diseases for which early diagnosis remains difficult.

\section{Acknowledgements}

The authors thank Doctor Carmen Burtea from the Department of General, Organic and Biomedical Chemistry, NMR and Molecular Imaging Laboratory, University of Mons, for providing the R826 peptide, Professor Jean-Pierre Brion of the Laboratory of Histology, Neuroanatomy and Neuropathology of the Free University of Brussels, Professor Gérard Toubeau and Annick Maes of the Department of Histology, University of Mons, Belgium, for numerous advice. We acknowledge Doctor David Sulzer of the Department of Neurology \& Psychiatry, Columbia University, New York, NY, and Department of Neuroscience, New York State Psychiatric Institute for advice on neuronal culture. The Center for Microscopy and Molecular Imaging (CMMI) is supported by the European Regional Development Fund and Wallonia. 


\section{References}

[1] Saunders CD. Parkinson's disease: A New Hope. Boston, MA: Harvard Health Publications. 2000.

[2] Goetz CG. Parkinson's disease diagnosis and clinical management. S. Factor and W. Weiner. Demos Medical Publishing. New York, USA. Charcot and Parkinson's disease. 2012; 19-26.

[3] Dauer W, Przedborski S. Parkinson's disease: mechanisms and models. Neuron. 2003; 39(6): 889-909. http://dx.doi.org/10.1016/S0896-6273(03)00568-3

[4] Levy OA, Malagelada C, Greene LA. Cell death pathways in Parkinson's disease: proximal triggers, distal effectors, and final steps. Apoptosis. 2009; 14(4): 478-500. PMid:19165601. http://dx.doi.org/10.1007/s10495-008-0309-3

[5] Fadok VA, Voelker DR, Campbell PA, et al. Exposure of phosphatidylserine on the surface of apoptotic lymphocytes triggers specific recognition and removal by macrophages. J. Immunol. 1992; 148: 2207. PMid:1545126.

[6] Hooper NM, Karran EH, Turner AJ. Membrane protein secretases. Biochem J. 1997; 321: 265-79. PMid:9020855. http://dx.doi.org/10.1042/bj3210265

[7] Tweedie D, Sambamurti K, Greig NH. TNF-alpha inhibition as a treatment strategy for neurodegenerative disorders: new drug candidates and targets. Curr. Alzheimer Res. 2007; 4(4): 378-85. http://dx.doi.org/10.2174/156720507781788873

[8] Sriram K, Matheson JM, Benkovic SA, et al. Mice deficient in TNF receptors are protected against dopaminergic neurotoxicity: implications for Parkinson's disease. FASEB J. 2002; 16(11): 1474-6. http://dx.doi.org/10.1096/fj.02-0216fje

[9] Czlonkowska A, Kohutnicka M, Kurkowska-Jastrzebska I, et al. Microglial reaction in MPTP (1-methyl-4- phenyl- 1, 2, 3, 6tetrahydropyridine) induced Parkinson's disease mice model. Neurodegeneration.1996; 5: 137-43. PMid:8819134. http://dx.doi.org/10.1006/neur.1996.0020

[10] Kohutnicka M, Lewandowska E, Kurkowska-Jastrzebska I, et al. Microglial and astrocytic involvement in a murine model of Parkinson's disease induced by 1-methyl-4-phenyl-1, 2, 3, 6-tetrahydropyridine (MPTP). Immunopharmacology. 1998; 39: 167-80. http://dx.doi.org/10.1016/S0162-3109(98)00022-8

[11] Kurkowska-Jastrzebska I, Wronska A, Kohutnicka M, et al. The inflammatory reaction following 1-methyl-4-phenyl-1, 2, 3, 6tetrahydropyridine intoxication in mouse. Exp. Neurol. 1999; 156: 50-61. PMid:10192776. http://dx.doi.org/10.1006/exnr.1998.6993

[12] Kaku K, Shikimi T, Kamisaki Y, et al. Elevation of striatal interleukin-6 and serum corticosterone contents in MPTP-treated mice. Clin. Exp. Pharmacol. Physiol. 1999; 26: 680-683. PMid:10499156. http://dx.doi.org/10.1046/j.1440-1681.1999.03113.x

[13] Grunblatt E, Mandel S, Maor G, et al. Gene expression analysis in N-methyl-4-phenyl-1, 2, 3, 6-tetrahydropyridine mice model of Parkinson's disease using cDNA microarray: effect of R-apomorphine. J. Neurochem. 2001; 78: 1-12. PMid:11432968. http://dx.doi.org/10.1046/j.1471-4159.2001.00397.x

[14] Mogi M, Togari A, Ogawa M, et al. Effects of repeated systemic administration of 1-methyl-4-phenyl-1,2,3,6-tetrahydropyridine (MPTP) to mice on interleukin-1beta and nerve growth factor in the striatum. Neurosci. Lett. 1998; 25: 25-8. http://dx.doi.org/10.1016/S0304-3940(98)00427-3

[15] Bloem BR, Irwin I, Buruma OJS, et al. The MPTP model: versatile contributions to the treatment of idiopathic Parkinson's disease. J. Neurol. Sci. 1990; 97: 273-93. http://dx.doi.org/10.1016/0022-510X(90)90225-C

[16] McGeer PL, Itagaki S, Boyes BE, et al. Reactive microglia are positive for HLA-DR in the substantia nigra of Parkinson's and Alzheimer's disease brains. Neurology. 1988; 38: 1285-91. PMid:3399080. http://dx.doi.org/10.1212/WNL.38.8.1285

[17] Przedborski S. Inflammation and Parkinson's Disease Pathogenesis Movement Disorders. Movement Disorder Society. 2010; 25(Suppl. 1): 55-7. PMid:20187228. http://dx.doi.org/10.1002/mds.22638

[18] Tatton NA, Kish SJ. In situ detection of apoptotic nuclei in the substantia nigra compacta of 1-methyl-4-phenyl-1, 2, 3, 6tetrahydropyridine-treated mice using terminal deoxynucleotidyl transferase labelling and acridine orange staining. Neuroscience. 1997; 77(4): 1037-48. http://dx.doi.org/10.1016/S0306-4522(96)00545-3

[19] Ferger B, Leng A, Mura A, et al. Genetic ablation of tumor necrosis factor-alpha (TNF- $\alpha$ ) and pharmacological inhibition of TNF-synthesis attenuates MPTP toxicity in mouse striatum. Journal of Neurochemistry. 2004; 89: 822-33. PMid:15140182. http://dx.doi.org/10.1111/j.1471-4159.2004.02399.x

[20] Furuya T, Hayakawa H, Yamada M, et al. Caspase-11 mediates inflammatory dopaminergic cell death in the 1-methyl-4- phenyl1,2,3,6-tetrahydropyridine mouse model of Parkinson's disease. J Neurosci. 2004; 24(8): 1865-72. PMid:14985426. http://dx.doi.org/10.1523/JNEUROSCI.3309-03.2004

[21] Sclavons C, Burtea C, Boutry S, et al. Phage display screening for tumor necrosis factor- $\alpha$-binding peptides: Detection of inflammation in a mouse model of hepatitis. Int J Pept. 2013; 2013: 348409. PMid:23533448. http://dx.doi.org/10.1155/2013/348409 
[22] Burtea C, Laurent S, Lancelot E, et al. Peptidic targeting of phosphatidylserine for the MRI detection of apoptosis in atherosclerotic plaques. Mol Pharm. 2009; 6(6): 1903-19. PMid:19743879. http://dx.doi.org/10.1021/mp900106m

[23] Burtea C, Ballet S, Laurent S, et al. Development of a magnetic resonance imaging protocol for the characterization of atherosclerotic plaque by using vascular cell adhesion molecule-1 and apoptosis targeted ultrasmall superparamagnetic iron oxide derivatives. Arterioscler Thromb Vasc Biol. 2012; 32: 36-48. PMid:22516067. http://dx.doi.org/10.1161/ATVBAHA.112.245415

[24] Ruehm SG, Christina H, Violas X, et al. Debatin. MR Angiography With a New Rapid-Clearance Blood. $2002 ; 8: 844-51$.

[25] Thorek DLJ, Chen AK, Czupryna J, et al. Superparamagnetic Iron Oxide Nanoparticle Probes for Molecular Imaging. 2006; 34: 23-38.

[26] Przedborski S, Khan U, Kostic V, et al. Increased superoxide dismutase activity improves survival of cultured postnatal midbrain neurons. J Neurochem. 1996; 67: 1383-92. PMid:8858919. http://dx.doi.org/10.1046/j.1471-4159.1996.67041383.x

[27] Rayport S, Sulzer D, Shi WX, et al. Identified postnatal mesolimbic dopamine neurons in culture: morphology and electrophysiology. J Neurosci. 1992; 12: 4264-80. PMid:1359033.

[28] Pothos E, Davila V, Sulzer D. Presynaptic recording of quanta from midbrain dopamine neurons and modulation of the quantal size. Journal of Neuroscience. 1998; 18: 4106-18. PMid:9592091.

[29] Ullmaiglg J, Seidlova F, Krekule J. 5-Fluorodeoxyuridine Inhibition of Photoperiodically Induced Flowering in Chenopodium rubrum L. BIOLOGIA PLANTARUM (PRAHA). 1971; 13 (5-6): 305-12.

[30] Bourque MJ, Trudeau LE. GDNF enhances the synaptic efficacy of dopaminergic neurons in culture. Eur J Neurosci. 2000; 12: 3172-80. http://dx.doi.org/10.1046/j.1460-9568.2000.00219.x

[31] Burke RE, Antonelli M, Sulzer D. Glial cell line-derived neurotrophic growth factor inhibits apoptotic death of postnatal substantia nigra dopamine neurons in primary culture. J Neurochem. 1998; 71: 517-25. PMid:9681441. http://dx.doi.org/10.1046/j.1471-4159.1998.71020517.x

[32] Shirvan A, Reshef A, Yogev-Falach M, et al. Molecular imaging of neurodegeneration by a novel cross-disease biomarker. Brain Stimulation in Psychiatry. 2009, 219: 274-83. http://dx.doi.org/10.1016/j.expneurol.2009.05.032

[33] Burtea C, Laurent S, Mahieu I, et al. In vitro biomedical applications of functionalized iron oxide nanoparticles, including those not related to magnetic properties. Contrast Media Mol Imaging. 2011; 6(4): 236-50. PMid:21861284.

[34] Yang YJ, Zhang S, Ding JH, et al. Iptakalim protects against MPP+-induced degeneration of dopaminergic neurons in association with astrocyte activation. Int J Neuropsychopharmacol. 2008; 12(3): 317-27. PMid:18700057. http://dx.doi.org/10.1017/S1461145708009243

[35] Lofrumento DD, Saponaro C, Cianciulli A, et al. MPTP-induced neuroinflammation increases the expression of proinflammatory cytokines and their receptors in mouse brain. Neuroimmunomodulation. 2011; 18(2): 79-88. PMid:20938211. http://dx.doi.org/10.1159/000320027 